\title{
BEST MANAGEMENT PRACTICES FOR SILVICULTURAL CHEMICALS AND THE SCIENCE BEHIND THEM ${ }^{\star}$
}

\author{
JERRY L. MICHAEL \\ USDA-FS, Southern Research Station, 520 Devall Drive, Auburn, AL 36849-5418, U.S.A. \\ (for correspondence,e-mail: michajl@auburn.edu)
}

\begin{abstract}
Silvicultural chemicals include fertilizers and pesticides applied for forest management. All states east of the Rockies have at least some form of silvicultural chemical best management practices (SCBMPs) and it is widely accepted that SCBMPs effect some protection of water quality. All SCBMPs recommend handling and application precautions and a minimum width streamside management zone (SMZ) on each side of streams for protection of water quality and aquatic ecosystems. Typically these zones increase in width as stream width increases. In areas where cold-water fish are present, additional widths are designated for their protection. Minimum SMZ widths range from 8 to 91 meters on each side of the stream bank for intermittent and perennial streams. Most SMZ recommendations do not cover ephemeral drainages, ditches or canals. SMZs are generally described as being site specific with width dependent on slope, soil type and other conditions as well as the stream's designation as perennial or intermittent. The science behind SCBMPs is often elusive. Spray drift can be controlled through proper selection and use of application technology while considering site specific conditions. SMZs greatly reduce the amount of herbicides reaching streams. Available toxicological data and research on aquatic ecosystem impacts from herbicide use suggest that additional protection from silvicultural chemicals may not be necessary. However, there is evidence to suggest that protection of ephemeral and intermittent channels can further reduce entry of silvicultural chemicals into streams and also reduce sedimentation. This may be the most fruitful area of research we can pursue in light of the knowledge gaps listed.
\end{abstract}

Keywords: BMP, ephemeral streams, fertilizers, herbicides, intermittent streams, perennial streams, silvicultural chemicals, SMZ, forestry

\section{Introduction}

Forest vegetation management activities significantly alter portions of the forest ecosystem. Activities that have the greatest impacts are harvest, planting site preparation, and management of competing vegetation. These activities occur principally at the end of one rotation and at the beginning of a new rotation and can result in movement of nutrients, pesticides and large amounts of sediment into streams. Depending on the crop species and the product for which it is grown, a rotation may last 20 to 80 years or more so most of the introduction of pollutants into streams occurs at the end of one rotation and beginning of another. Vegetation control and fertilization may occur 2-3 times during a rotation. Depending on the tool used the attendant ecosystem changes can be significant on the temporal and local

^ The U.S. Government's right to retain a non-exclusive, royalty free licence in and to any copyright is acknowledged.

Water, Air, and Soil Pollution: Focus 4: 95-117, 2004.

(c) 2004 Kluwer Academic Publishers. Printed in the Netherlands. 
scale. Along with changes in the landscape comes changes in wildlife habitat and potentially the associated aquatic ecosystem. Most timber producing countries in the world have instituted forest regulations in an effort to respond to concerns over potential changes in site productivity, water quality, and to promote sustainability. Authorizing regulations in the U.S.A. include the Federal Insecticide, Fungicide, and Rodenticide Act (FIFRA); the National Environmental Policy Act 1969 and as amended; the Endangered Species Act 1973; and the Clean Water Act of 1977 and as amended.

There are three inter-related components of water quality protection from silvicultural chemicals in the U.S.A.: 1) Use of Best Management Practices (BMPs) to protect against water contamination from direct application to water, drift, movement through the soil profile to groundwater, and overland flow; 2) Toxicity which is a function of frequency and duration of exposure and the dose received at each exposure; 3) Risk-based assessment to determine what constitutes an unreasonable adverse effect on the environment. The latter is mandated by Congress under FIFRA $\S 3(\mathrm{c})(5)$, (8). Regulatory authority is vested in the individual states and takes the form of Best Management Practices (BMPs). These BMPs may be voluntary or mandatory, depending on the state, and are developed in each state to help landowners and forestry practitioners protect water quality.

Water quality includes the physical, chemical and biological attributes of water, but the terminology and measures that have been devised and codified for its protection are diverse among countries, provinces, and states. Herein the terms streamside management zone, riparian management zone, special management zone, streamside reserve, will all be represented by the abbreviation SMZ. An SMZ is a designated area that consists of the stream and an adjacent area of varying width where management practices that might impact water quality are modified or restricted. The standard convention for expressing SMZ width is to indicate the width on one side of the stream measuring from the streambank. For ephemeral or intermittent streams with nearly nondefined banks, it is usually expressed from the middle of the channel. SMZs may include many components depending on geography, topography, and purpose of the regulation. An SMZ may include such components as buffers, filter strips, primary zones, secondary zones, stringers, etc.

SMZ width recommended in BMPs may range from no recommendation in some instances for intermittent and ephemeral streams to more than $90 \mathrm{~m}$ for perennial streams. The issues of sedimentation, wildlife habitat and rare and endangered plant species are very important, but these issues are outside the scope of this paper which is concerned only with water quality. The purpose of this paper is to review the silvicultural chemical best management practices (SCBMPs) established by states east of the Rocky Mountains (excluding ND, SD, KA, OK, MA, and RI). 
TABLE I

Percent of states east of the Rocky Mountains in U.S.A. (ND, SD, KA, OK, MA, and RI are not included) recommending minimum SMZ widths indicated (see Table II for specific information and references)

\begin{tabular}{lccll}
\hline $\begin{array}{l}\text { Minimum width } \\
\text { in ft (m) }\end{array}$ & \multicolumn{3}{l}{ Stream designation } & \\
\cline { 2 - 5 } & Perennial & Intermittent & Ephemeral & $\begin{array}{l}\text { Ditches, } \\
\text { canals, etc. }\end{array}$ \\
\hline NSR $^{\mathrm{a}}$ & 0 & 12.9 & 80.6 & 93.5 \\
Protect $^{\mathrm{b}}-20(6.1)$ & 0 & 6.5 & 16.1 & 6.5 \\
$21-35(6.4-10.7)$ & 38.7 & 45.2 & 3.2 & 0 \\
$36-50(11-15.2)$ & 48.4 & 25.8 & 0 & 0 \\
$>50(15.2)$ & 12.9 & 9.7 & 0 & 0 \\
\hline
\end{tabular}

${ }^{a}$ No specific SMZ width recommendation given.

b No specific width indicated, but 'protection' recommended. Some indicate use of vegetative filter strip, stringer (a narrow strip of trees left for stabilization of soil), or treatment as intermittent if ephemeral transitions into intermittent.

\section{States' Recommendations}

Silvicultural chemical BMPs apply to fertilizers and pesticides used on forest sites for management of crop trees. In this context, pesticides and fertilizers are applied as needed to improve growth and yield and for protection of the crop tree from a host of pests, including competing vegetation. The use of herbicides in silvicultural activities may occur two or three times in the period of a rotation, typically 20-80 years depending on the crop tree and the product for which it is grown (lumber, pulp, etc.). BMPs recommended by the various states for protection of water quality include several levels of specificity based primarily on stream classification, hillside slope, soils, and presence of anadromous fish (Tables I and II). Most states combine considerations of water quality as affected by use of fertilizers and pesticides into the SCBMP and the most common aspect of that BMP is the recommendation concerning SMZ width. Other recommendations found in SCBMPs are largely founded on common sense and the law explicit on manufacturer's product labels for pesticides. For specific details for individual states, please consult Table II for references to those states.

Silvicultural chemical BMPs are comprised of general guidelines, voluntary in some states and mandatory in others. The diversity of land ownerships, values states' citizens place on forest land, variety of landowner owner goals and objectives coupled with some federal and state regulations governing water quality insure a variety of general guidelines. While the states' guidelines vary slightly in wording there are some constants that allow for a summary of the states' BMPs. Most states have in common the recommendation of specific SMZ widths for the protection of water quality. The remaining general guidelines fall into several cat- 
TABLE II

Minimum streamside management zone width recommendations by stream classification for individual states east of the Rocky Mountain states in the U.S.A. and the variables used to customize SMZ width for specific conditions. Some states have no specific recommendations (NSR) in their manuals while others say protection may be needed. Recommendations for control of spray drift into SMZs are also included

\begin{tabular}{|c|c|c|c|c|c|c|}
\hline \multirow[t]{2}{*}{ State } & \multirow[t]{2}{*}{ Variables ${ }^{a}$} & \multicolumn{3}{|c|}{ Stream classification } & \multirow{2}{*}{$\begin{array}{l}\text { Drift } \\
\text { control }\end{array}$} & \multirow[t]{2}{*}{ Reference } \\
\hline & & $\begin{array}{l}\text { Ephemeral } \\
\mathrm{ft}(\mathrm{m})\end{array}$ & $\begin{array}{l}\text { Intermittent } \\
\mathrm{ft}(\mathrm{m})\end{array}$ & $\begin{array}{l}\text { Perennial } \\
\mathrm{ft}(\mathrm{m})\end{array}$ & & \\
\hline Alabama & NSR & NSR & $35(10.7)$ & $35(10.7)$ & Follow label & AFC 1999 \\
\hline Arkansas & $\mathrm{Sl}$ & NSR & $35(10.7)$ & $35(10.7)$ & Follow label & ARFC 2002 \\
\hline Connecticut & $\mathrm{S} 1$ & NSR & $25(7.6)$ & $25(7.6)$ & NSR & CRCD 1998 \\
\hline Delaware & $\mathrm{E}, \mathrm{Sl}$ & $\begin{array}{l}\text { Protect, } \\
\text { NSR }\end{array}$ & $50(15.2)$ & $50(15.2)$ & $\begin{array}{l}\text { Follow label, } \\
\text { prevent drift }\end{array}$ & DDAFS 2002 \\
\hline Florida & E, Sl, SW & NSR & Stringer & $35(10.7)$ & $\begin{array}{l}\text { Keep out } \\
\text { of SMZ }\end{array}$ & FDOF 2000 \\
\hline Georgia & $\mathrm{S} 1, \mathrm{Tr}$ & $20(6.1)$ & $20(6.1)$ & $40(12.2)$ & Avoid drift & GFC 1999 \\
\hline Illinois & $\mathrm{S} 1$ & NSR & 25 (7.6) & $50(15.2)$ & $\begin{array}{l}\text { Follow label, } \\
\text { prevent drift }\end{array}$ & IDFR 2000 \\
\hline Indiana & Sl, SW & $\begin{array}{l}\text { No spray, } \\
\text { NSR }\end{array}$ & 25 (7.6) & $50(15.2)$ & Follow label & IDF 1998 \\
\hline Iowa & SW & NSR & NSR & $50(15.2)$ & $\begin{array}{l}\text { Follow label, } \\
\text { prevent drift }\end{array}$ & $\begin{array}{l}\text { IDNR not } \\
\text { dated }\end{array}$ \\
\hline Kentucky & S1 & NSR & $25(7.6)$ & $25(7.6)$ & Follow label & KDF 2001 \\
\hline Louisana & SW & $\begin{array}{l}\text { Maintain } \\
\text { vegetated } \\
\text { filter strip, } \\
\text { NSR }\end{array}$ & $35(10.7)$ & $50(15.2)$ & Follow label & LDAF 2001 \\
\hline Maine & NSR & NSR & $75(22.9)$ & $75(22.9)$ & $\begin{array}{l}\text { Minimize } \\
\text { drift }\end{array}$ & $\begin{array}{l}\text { MDEP } 2000 \\
\text { MBPC not } \\
\text { dated }\end{array}$ \\
\hline Maryland & NSR & NSR & $35(10.7)$ & $35(10.7)$ & NSR & $\begin{array}{l}\text { Tjaden and } \\
\text { Weber } 1998\end{array}$ \\
\hline Michigan & $\mathrm{Sl}$ & NSR & $100(30.5)$ & $100(30.5)$ & $\begin{array}{l}\text { Follow label, } \\
\text { prevent drift }\end{array}$ & $\begin{array}{l}\text { MDEQ not } \\
\text { dated } \\
\text { Hausler and } \\
\text { Peterson } 2001\end{array}$ \\
\hline Minnesota & $\begin{array}{l}\text { FT, MS, Sl, } \\
\text { SW, Tr }\end{array}$ & NSR & NSR & $50(15.2)$ & $\begin{array}{l}\text { Minimize } \\
\text { drift }\end{array}$ & MFRC 1999 \\
\hline Mississippi & $\mathrm{S} 1$ & NSR & $30(9.1)$ & $30(9.1)$ & NSR & MFC 2000 \\
\hline Missouri & $\mathrm{S} 1$ & NSR & $25(7.6)$ & $25(7.6)$ & NSR & MDC 2000 \\
\hline Nebraska & SW & NSR & NSR & 50 & Follow label & NFS 1998 \\
\hline
\end{tabular}


TABLE II

(Continued)

\begin{tabular}{|c|c|c|c|c|c|c|}
\hline \multirow[t]{2}{*}{ State } & \multirow[t]{2}{*}{ Variables $^{\mathrm{a}}$} & \multicolumn{3}{|c|}{ Stream classification } & \multirow{2}{*}{$\begin{array}{l}\text { Drift } \\
\text { control }\end{array}$} & \multirow[t]{2}{*}{ Reference } \\
\hline & & $\begin{array}{l}\text { Ephemeral } \\
\mathrm{ft}(\mathrm{m})\end{array}$ & $\begin{array}{l}\text { Intermittent } \\
\mathrm{ft}(\mathrm{m})\end{array}$ & $\begin{array}{l}\text { Perennial } \\
\mathrm{ft}(\mathrm{m})\end{array}$ & & \\
\hline New Hampshire & $\mathrm{S} 1$ & NSR & $50(15.2)$ & $50(15.2)$ & NSR & DRED 2001 \\
\hline New Jersey & $\mathrm{Sl}, \mathrm{E}$ & NSR & 25 & 25 & $\begin{array}{l}\text { Maintain } \\
50 \mathrm{ft} \text { buffer } \\
\text { for aerial } \\
\text { application } \\
\text { follow label, } \\
\text { avoid drift }\end{array}$ & NJBFM 1995 \\
\hline New York & $\mathrm{S} 1$ & NSR & 50 & 50 & NSR & NYS 2000 \\
\hline North Carolina & $\mathrm{Sl}, \mathrm{Tr}$ & NSR & $50(15.2)$ & $50(15.2)$ & Follow label & $\begin{array}{l}\text { NCDFR } 1989 \\
\text { NCDFR } 2003\end{array}$ \\
\hline Ohio & $\mathrm{S} 1$ & NSR & $25(7.6)$ & $25(7.6)$ & NSR & ODNR 1992 \\
\hline Pennsylvania & $\mathrm{S} 1$ & NSR & NSR & 25 & NSR & $\begin{array}{l}\text { PSU } 1999 \\
\text { PDEP } 1999\end{array}$ \\
\hline South Carolina & $\mathrm{Sl}, \mathrm{Tr}$ & $\begin{array}{l}\text { Protect, } \\
\text { NSR }\end{array}$ & $40(12.2)$ & $40(12.2)$ & $\begin{array}{l}\text { Follow label, } \\
\text { avoid drift }\end{array}$ & $\begin{array}{l}\text { SCFC } \\
\text { not dated }\end{array}$ \\
\hline Tennessee & $\mathrm{Sl}$ & $\begin{array}{l}\text { Protect, } \\
\text { NSR }\end{array}$ & $25(7.6)$ & $25(7.6)$ & $\begin{array}{l}\text { Follow label, } \\
\text { avoid drift }\end{array}$ & $\begin{array}{l}\text { TDADF } 1993 \\
\text { UTAES } 1995 \\
\text { TDADF } 2000\end{array}$ \\
\hline Texas & $\mathrm{Sl}$ & NSR & $50(15.2)$ & $50(15.2)$ & $\begin{array}{l}\text { Follow label, } \\
\text { avoid drift }\end{array}$ & TFS 2000 \\
\hline Vermont & $\mathrm{Sl}$ & NSR & $50(15.2)$ & $50(15.2)$ & NSR & DPFR 1987 \\
\hline Virginia & $\mathrm{Sl}, \mathrm{Tr}$ & NSR & $50(15.2)$ & $50(15.2)$ & $\begin{array}{l}\text { Do not } \\
\text { apply when } \\
\text { wind speed } \\
>5 \mathrm{mph}\end{array}$ & VDF 2002 \\
\hline West Virginia & NSR & $25(7.6)$ & $100(30.5)$ & $100(30.5)$ & NSR & WVDF 2001 \\
\hline Wisconsin & NAV & NSR & 35 (10.7) & $100(30.5)$ & $\begin{array}{l}\text { Follow label, } \\
\text { prevent drift, } \\
\text { use drift } \\
\text { control agent }\end{array}$ & WDNR 2002 \\
\hline
\end{tabular}

a Variables for which states have given in their BMPs specific recommendations for increasing the minimum recommended SMZ width: E, erodibility; FT, forest type; MS, management system (even-age vs. uneven-age); $\mathrm{NAV}$, navigability; Sl, slope; SW, stream width; $\mathrm{Tr}$, designation as trout or non-trout stream. Stringer, narrow strip of trees left for stabilization of soil, no width specified. 
egories: following all product label instructions; disposal of excess chemical and containers; how, when, and where to apply or not apply; maintenance and service of application equipment; prevention of direct application to surface water, and prevention of contamination by drift; and what to do in case of spills. It is not possible to include each SCBMP general guideline for each state, but they can be summarized to some extent by sacrificing some details. The summary (with the states recommending the general guideline in parentheses, see Table II for individual state BMP manual references) below is generalized in this way and the reader is directed to seek specific information for any state of interest:

- Follow silvicultural chemical label instructions (AR, DE, GA, IL, IA, LA, MI, MN, NC, NJ, SC, TN, TX, VA, WI).

- Properly dispose of excess chemicals and empty containers (AR, FL, GA, IA, LA, MI, NC, SC, VA).

- Apply at appropriate rates (AR, IL, IA, KY, LA, NC, SC).

- Do not apply fertilizer in SMZs (AL, FL, GA, IN, KY, MS, NC).

- Do not handle, mix, or store pesticides or fertilizers in SMZs (GA, IL, IA, LA, MN, NC, NJ, SC, TX, VA, WI).

- Do not allow silvicultural chemicals to leak from equipment (AR, IL, IA, LA, WI).

- Do not service application equipment near streams (AR, GA, MI, MS, NC, TX).

- Minimize use of streams, lakes, ponds or rivers as sources of water for mixing of silvicultural chemicals (AR, LA, TX, WI).

- Do not apply immediately before precipitation or after if there is still runoff (AR).

- Clean up and report all chemical spills immediately (GA, IL, IA, LA, MN, $\mathrm{NC}, \mathrm{SC}, \mathrm{TX}, \mathrm{WI})$.

- Do not use broadcast herbicide applications where excessive runoff will be a problem (IN, IA, LA).

- Do not broadcast apply pesticides in SMZs (FL, GA, IL, IN, LA, MS, MS, MO, NC, SC, VA).

- Consider weather conditions, equipment and chemical fomulations to avoid drift into streams (AR, DE, FL, GA, IL, IN, IA, LA, MI, MN, NC, NJ, SC, TN, TX, VA, WI).

- Shut off chemical application during turns over open water (LA, TX).

- Do not apply directly to water unless registered for aquatic use (AL, GA, LA, MN, MS, NC, SC, TN, TX, VA).

The categories above are not mutually exclusive. The first category is follow label instructions, but most labels have instructions covering the next two, disposal of containers and following recommended application rates. The categories above generalize the kinds of recommendations made by the various states in their efforts to protect water quality. 
The key to maintaining water quality is protection of streams from direct application of pesticides and fertilizers, principally through the appropriate and judicious application of SMZs to different classes of streams. Streams may be classified in many ways, but the simplest classification is in terms of the amount and seasonality of water passing through them. Perennial streams flow most of the year and include a well defined channel. Intermittent streams also contain a well defined channel and flow through the year, but flow is more seasonal and usually present in the wet portions of the year. Ephemeral streams may have poorly- or un-defined channels and frequently contain decaying and fresh organic matter during portions of the year, but usually exhibit surface scouring following precipitation events. Flow in these portions of streams occurs only in response to rainfall or snowmelt. Ephemeral drains are frequently connected directly to intermittent and perennial channels such that any sediment, fertilizer or herbicide moving in them flows directly into intermittent and perennial streams. Ditches and canals are artificial channels that also contribute to streamflow. They are usually deeply incised into the topography sharing the common feature of a defined channel with perennial streams. Ditches and canals may be ephemeral, intermittent or perennial and are frequently connected to intermittent or perennial streams.

SMZs are universally applied to perennial streams and other bodies of water. SMZs are frequently applied to intermittent streams, but ephemeral streams, ditches and canals are often left unprotected by SMZs. It is widely recognized that the maintenance of SMZs protect water quality to varying degrees, and it is common to recommend greater widths for more protection. In the United States of America east of the Rocky Mountains, for example, a survey of SMZ widths for streams of various types shows $80.6 \%$ of the states do not recommend protection of ephemeral drains and $93.5 \%$ do not recommend protection of drains, canals and ditches (Table I).

SMZ width in some states is based on stream width (Table II). Florida's SMZ width recommendations for perennial streams located on soils rated as low erodibility and on hillside slope of $2 \%$ or less are $35 \mathrm{ft}$ for streams $<20 \mathrm{ft}(6.1 \mathrm{~m})$ in width, $75 \mathrm{ft}(22.9 \mathrm{~m})$ for streams $20-40 \mathrm{ft}(6.1-12.2 \mathrm{~m})$ in width, and $200 \mathrm{ft}(61 \mathrm{~m})$ for streams $>40 \mathrm{ft}$ in width (FDOF, 2000). Minnesota recommends SMZ widths of $50 \mathrm{ft}$ for streams $<3 \mathrm{ft}(0.9 \mathrm{~m})$ in width and $100 \mathrm{ft}(30.5 \mathrm{~m})$ for streams $>10 \mathrm{ft}$ (3.0 $\mathrm{m}$ ) in width (MFRC, 1999) while Louisana recommends $50 \mathrm{ft}$ width for streams $<20 \mathrm{ft}$ wide and $100 \mathrm{ft}$ for streams $>20 \mathrm{ft}$ in width (LDAF, 2001). It is clear that some states' SMZ recommendations are based on the assumption that wider SMZs are more protective of water quality than narrower. However, the ephemeral stream portion of any river system may be quite large. For example 55\% of the total stream network in the Chattooga River System in the Southern Appalachians is composed of ephemeral streams while $28 \%$ are perennial and $17 \%$ are intermittent (Hansen, 2001). Clearly, more than half of that system is ephemeral in nature. Thus, most of the stream network in the Chattooga River system (and other similar river systems) is not protected under current SCBMP SMZ width recommendations. Considering 
the variable source-area watershed concept, in which source of runoff expands in area through an increase in flow from intermittent and ephemeral channels, length rather than width may be the most important factor for protection against chemical pollutants and sediment transport. In fact, some states (GA, LA, SC, TN, WV) recognize that if an ephemeral channel transitions into an intermittent stream there is the possibility of pollutants moving in that continuum to the intermittent and subsequently to the perennial streams. These states recommend protection of such ephemeral streams either as intermittent, through the use of specified SMZ widths, or by the use of special precautions such as maintenance of filter strips or protection of litter (Table II).

\section{Scientific Basis for Silvicultural Chemical BMPs}

Almost all states recommend a minimum SMZ width and many stipulate increases in width based on such factors and combinations of factors as stream width, slope of adjacent land, soil erodibility, and whether the affected stream is populated with cold or warm water fish (Table II). A few states make additional SMZ width recommendations based on whether the stream is navigable, even intermittent streams may be considered navigable if a canoe can be maneuvered during wet seasons (WDNR, 2002). Minnesota recommends chemical characteristics (water solubility greater than $30 \mathrm{mg} \mathrm{L}^{-1}$, Koc less than 300-500, and half-life greater than 21 days) which should be avoided in order to reduce leaching potential to groundwater and runoff to surface water (MFRC 1999). These characteristics, should they become mandatory, would preclude the use of herbicides past and presently registered by EPA (Table III). The basis for BMP recommendations is sometimes well founded and at others appears to be more political than scientific. The scientific basis is built on a consideration of toxicity and of potential for contamination from drift, leaching through the soil profile to groundwater, and storm runoff. A few field studies have investigated the actual impacts on aquatic ecosystems and have extrapolated potential adverse impacts on water quality based on observed levels of contamination and toxicological data. The following discussion will focus primarily on herbicides.

\subsection{TOXICITY}

There are several terms useful in any discussion of toxicity. The term $\mathrm{LD}_{50}$ is in popular use and denotes the dose, which kills half the test organisms. While toxicity testing is not generally conducted on humans, several surrogate mammalian species are used for tests. However, $\mathrm{LD}_{50}$ is not a very useful concept since it means that half of the animals die and the other half are probably very sick. A more acceptable and useful term is the no observable effect level (NOEL, or concentration, NOEC). The NOEL/NOEC is the highest exposure at which no effect on the test organism is 
TABLE III

Properties of some silvicultural chemicals. Data for properties are from Wauchope et al., 1992

\begin{tabular}{lrrl}
\hline Pesticide & $\begin{array}{l}\text { Water solubility } \\
\left(\mathrm{mg} \mathrm{L}^{-1}\right)\end{array}$ & $\mathrm{K}_{\mathrm{oc}}$ & $\begin{array}{l}\text { Soil half-life } \\
\text { (days) }\end{array}$ \\
\hline Clopyralid & 300000 & 6 & 40 \\
2,4-D ester & 100 & 100 & 10 \\
Glyphosate & 900000 & 24000 & 47 \\
Hexazinone & 33000 & 54 & 90 \\
Imazapyr & 500000 & 100 & 90 \\
Metsulfuron & 9500 & 35 & 30 \\
Picloram & 200000 & 16 & 90 \\
Sulfometuron & 70 & 78 & 20 \\
Triclopyr ester & 23 & 780 & 46 \\
\hline
\end{tabular}

observed. The oral reference dose (RfD) is the total amount of a pesticide that can be consumed daily over a lifetime without adverse health effects. Calculated from the lowest animal NOEL, EPA applies an additional safety factor of 100 (10 for interspecific and 10 for intraspecific variation) to 1000 depending on their estimate of the reliability of available data. Another measure of relative safety to mammals is the health advisory level (HAL), the maximum concentration allowable for a herbicide in drinking water, which if consumed daily over a lifetime would not be expected to cause adverse health effects. HALs can be approximated by scaling $10 \%$ of the RfD up to $70 \mathrm{~kg}$ to represent a $70 \mathrm{~kg}$ adult (Table IV). Most herbicides registered for forestry use in the U.S. are classified in Cancer Groups D or E, either not classifiable as to human carcinogenicity (D) or evidence of noncarcinogenicity (E) and the risk of developing cancer from exposure to these chemicals is currently assessed as less than 1 in 100 000. The HALs, RfDs, and NOELs from Table IV can be used to evaluate potential toxicity from herbicide values observed in water. It should be remembered that every chemical, natural or synthetic, including water is toxic. A recent incident in Springville, Utah points out all too vividly how toxicity of even the most innocuous compounds may lead to death when sufficient exposure occurs (ABCNews, 2002). In this incident, a four-year-old child died after drinking large quantities of water. The mode of action in this case is believed to be the lowering of sodium concentration in the child's blood. Decreased blood sodium levels triggered brain swelling and caused the child's death. The amount and route of exposure determine whether organisms will be adversely affected by toxicity. Even the most toxic compounds can be relatively innocuous when exposures are sufficiently low. 
TABLE IV

Toxicity of some herbicides. From U.S. Environmental Protection Agency sources (http://www. epa.gov/waterscience/drinking/standards/dwstandards.pdf) and Office of Drinking Water. Cancer Groups D, not classifiable as to human carcinogenicity; E, evidence of noncarcinogenicity

\begin{tabular}{llllcll}
\hline Herbicide & $\begin{array}{l}\text { Cancer } \\
\text { group }\end{array}$ & $\begin{array}{l}\mathrm{HAL}^{\mathrm{a}} \\
(\mathrm{mg} / \mathrm{L})\end{array}$ & $\begin{array}{l}\text { Oral RfD } \\
(\mathrm{mg} / \mathrm{kg} / \mathrm{day})\end{array}$ & $\begin{array}{l}\text { Mammalian } \\
\text { NOEL } \\
(\mathrm{mg} / \mathrm{kg} / \text { day })\end{array}$ & $\begin{array}{l}\text { Aquatic } \\
\text { NOEC } \\
(\mathrm{mg} / \mathrm{L})\end{array}$ & $\begin{array}{l}\text { Aquatic } \\
\text { NOEC } \\
\text { references }\end{array}$ \\
\hline 2,4-D (acid) & $\mathrm{D}$ & 0.07 & 0.01 & $1-37$ & $2-110$ & USDA, 1984 \\
Glyphosate & $\mathrm{D}$ & 0.7 & 0.1 & $10-500$ & $25-50$ & USEPA, 1993 \\
Hexazinone & $\mathrm{D}$ & 0.4 & 0.05 & $10-250$ & $10->80$ & USEPA, 1994 \\
Imazapyr & $\mathrm{E}$ & {$[17]$} & 2.5 & $300-10000$ & $0.024->100$ & SERA, 1999 \\
Metsulfuron & $\mathrm{D}$ & {$[1.75]$} & 0.25 & $25-700$ & $>150$ & PIP 1993 \\
Sulfometuron & $\mathrm{D}$ & {$[0.14]$} & 0.02 & 50 & $>1.2$ & SERA, 1998 \\
Triclopyr & $\mathrm{D}$ & {$[.35]$} & 0.05 & $2.5-240$ & NA & USEPA, 1998 \\
\hline
\end{tabular}

${ }^{\mathrm{a}}$ Brackets enclose an approximated $\mathrm{HAL}=(0.1 * \mathrm{RfD}) *(70)$.

NA, not available for triclopyr acid; triclopyr triethylamine salt (Garlon 3A) has NOECs ranging from 80.7 to $104 \mathrm{mg} / \mathrm{L}$ for aquatic organisms and is categorized as practically nontoxic to slightly toxic; aquatic organism NOECs not available for triclopyr butoxyethyl ester (Garlon 4E) which is rated as moderately to highly toxic for these organisms.

\subsection{DRIFT DURING APPLICATION}

Spray drift is the movement of spray droplets or vapors from the target area to areas where application was not intended and can contaminate streams. Spray drift occurs when droplets formed by the application nozzles move with a trajectory different than straight down. Spray nozzles are designed to maximize the amount of spray that actually hits its target and save on application costs; however, under the right conditions very small droplets may move a mile or more off site. Herbicide granules or dried particles of herbicides may move from the target area in high winds but are not considered important sources of herbicide drift. Low levels of drift may pose no environmental hazard.

Spray drift is one of the components of stream contamination for which we have a solid scientific background and understanding. We can come very close, with simple mathmatical calculations, to determining how far a droplet of known mass will travel under specific conditions of speed and height of application and therefore how wide an SMZ will be required to minimize contamination of streams. There are some very sophisticated models like AgDRIFT, FSCBG, and AGDISP (FEMVTF, 2002), which give an even better estimate of required SMZ width (Teske and Ice, 2002; Payne et al., 1988). These models take into consideration spray nozzle drop distribution patterns which describe the mass of any spray pattern that occurs in drops of various particle sizes, wind speed and direction, height of 
application and SMZ porosity to estimate the amount of contamination that may occur from specific applications. This information, when used in conjunction with toxicological data for aquatic organisms, allows one to calculate the SMZ width needed to afford a specified level of protection to organisms in streams and to define the conditions under which spraying can be allowed.

Payne and others $(1988,1990)$ have used the modeling approach to calculate SMZ width. Payne et al., (1988) determined that $65.6 \mathrm{ft}(20 \mathrm{~m})$ was sufficient to protect streams and limit mortality of Aedes aegypti (yellow fever mosquito) to less than $10 \%$ from an application of permethrin at the rate of $0.035 \mathrm{~kg} \mathrm{ha}^{-1}$. The species they were most interested in protecting was trout, a species relatively tolerant of permethrin. Aedes aegypti was selected as the indicator species in this study because it was considered the most sensitive species in the stream. In a study on glyphosate, Payne et al., (1990) set the toxicological endpoint conservatively for trout protection from glyphosate at $1 \mathrm{mg} \mathrm{L}^{-1}$ even though the 96-hr $\mathrm{LC}_{50}$ was 52 $55 \mathrm{mg} \mathrm{L}^{-1}$ and determined the required SMZ width was $82 \mathrm{ft}(25 \mathrm{~m})$. Using EPA's level-of-concern approach, $5 \mathrm{mg} \mathrm{L}^{-1}$ may have been a more reasonable end-point and it would have resulted in a much narrower SMZ. Hildebrand et al. (1980) also demonstrated in field tests that peak glyphosate stream concentrations of 249-480 $\mathrm{mg} \mathrm{L}^{-1}$ had no effect on rainbow trout mortality and resulted in $90 \%$ survival of Daphnia magna. This value is greater than EPA's value of $25 \mathrm{mg} \mathrm{L}^{-1}$ for trout NOEC. It is clear that the toxicological endpoint used to determine acceptable water concentrations greatly affects width of SMZ. The important point here is that one must select the species or organisms to be protected, establish concentrations that will effect that protection, and then calculate the required SMZ width. For very precise calculations of SMZ width for adequate drift protection of stream ecosystems, good toxicological data and knowledge of the composition of the aquatic communities within the stream are necessary.

\subsection{LEACHING THROUGH THE SOIL PROFILE}

Herbicide movement through soil, except in the case of macropore transport, is relatively slow and most forest herbicides have not been detected at great depths in the soil profile. Glyphosate is almost immobile in soil and is not thought to move through the soil below $15 \mathrm{~cm}$ (EPA, 1993). Triclopyr has been found to move to depths of 10-30 cm (Lee et al., 1985, Stephenson et al., 1990). Hexazinone, perhaps the most studied non-phenoxy forestry herbicide, has been detected at depths down to $75 \mathrm{~cm}$, but more commonly is not detected below about $50 \mathrm{~cm}$ (Roy et al., 1989, Feng and Navratil 1990, Allender 1991, Michael et al., 1999). Imazapyr is rarely detected at $50 \mathrm{~cm}$, but is known to move below $30 \mathrm{~cm}$ in several soil types (Rahman et al., 1993). Similarly, the sulfonyl ureas (sulfometuron and metsulfuron) are known to move to $50 \mathrm{~cm}$, but are not reported to move significantly below $70 \mathrm{~cm}$ (Walker and Welch, 1989, Lym and Swenson, 1991). In the process 
of movement through the soil profile, herbicides are acted upon by a variety of degradative and dilution processes.

Biological and chemical degradation play a large role in reduction of herbicide movement through soil profiles with the end result being destruction of the herbicide molecule. The residence time of silvicultural chemicals in a given layer of soil (e.g., 0-15 cm depth) is described in terms of half-life or the time required for dissipation of half of the beginning concentration (Michael and Neary, 1993). Half-lives of some silvicultural chemicals currently in use are presented in Table III. Advective dispersion also contributes to the chemical and biological degradation by slowing the movement of herbicide through the soil profile. This form of dispersion is like that observed in chromatographic systems in which the solute front is partially retarded by interaction with the chromatographic medium, soil in this case. The retardation of movement both dilutes the front (resulting in reduced concentrations observable at greater soil depths) and retains the herbicide in the root zone for a longer period of time during which degradation can occur. Soils with more organic matter and clay provide for greater advective dispersion of nonpolar pesticides. This process and the attendant lack of significant movement through the soil profile preclude significant groundwater contamination by forestry herbicides (Michael, 2000).

The greater the capacity for water (and therefore soluble herbicides) movement through the soil profile, the lower is the potential for overland flow. Overland flow occuring shortly after herbicide application potentially contains very high concentrations of herbicide which it carries to streams. Because of its short residence time prior to entry into streams, overland flow results in higher levels of stream contamination than that observed from herbicide which has leached through the soil profile and entered streams through baseflow (Michael and Neary, 1993; Michael et al., 1999; Michael 2003).

\subsection{STREAM CONTAMINATION DURING APPLICATION AND STORM RUNOFF}

The results of several studies, which monitored the environmental fate of forestry herbicides used in the southern United States, have been reported (Michael and Neary, 1993). Another report (Michael, 2000) summarized surface and groundwater contamination data from reports for North America published between 1974 and 2000. It is clear from these reports that the maximum concentrations of herbicide observed in streams is related to the method of application. Broadcast applications generate the highest concentration which is often observed on the day of application. Broadcast applications permit less control over herbicide placement and frequently result in application of herbicide into ephemeral and intermittent stream channels. If application to ephemeral or intermittent channels occurs during a time when they contain water, movement into perennial channels is inevitable, even when the perennial stream is protected with an SMZ. Under these conditions, aerial broadcast applications may result in 0.4 to $0.6 \mathrm{mg} \mathrm{L}^{-1}$ of herbicide in streams on 
the day of application while concentrations resulting from overland flow during the first storm typically do not exceed 0.2 to $0.4 \mathrm{mg} \mathrm{L}^{-1}$, even when the application rate is 3 to 4 times the prescribed rate. Periods between storms, principally composed of baseflow, are characterized by herbicide concentrations near or below analytical detection limits (Michael and Neary, 1993, Michael et al., 1999; Michael, 2003). Each subsequent storm results in stream contamination at decreasing levels until the 4th or 5th storm at which time herbicides are typically not detected in streams draining treated areas. The peak concentrations observed in streams, whether on the day of application or during storm events, are short-lived and last from a few minutes to a few hours. During storm runoff, concentrations are greatest around peak discharge for the storm event and seldom last longer than 30 minutes, but even these highest observed concentrations seldom exceed drinking water quality standards.

Single stem injection treatments (herbicide is injected directly into each plant to be killed) and spot applications (placement of herbicide directly onto the soil surface) result in observed stream contamination levels up to $0.04 \mathrm{mg} \mathrm{L}^{-1}$. These methods of application permit the maximum amount of control over where the herbicides are applied and it is very easy to keep them out of stream channels during application.

Herbicide may also move through the SMZ via overland flow and into streams. The concern over movement of pollutants (herbicides, nutrients, sediment, etc.) from hillside slopes through the SMZ and into streams has resulted in many states' use of hillside slope as a basis for increasing the SMZ width beyond established minimum standards. The formula takes the general form:

$\mathrm{SMZ}$ width $=$ minimum base width $+\mathrm{X}$ feet per $\mathrm{Y}$ change in $\%$ slope

where the minimum base width varies by state and stream type (Table II). The amount of change $(\mathrm{X})$ and the change in percent slope categories (Y) also vary by state. Some states recommend a nearly linear change (e.g., $10 \mathrm{ft}$ for each 5\% of slope up to $40 \%$ in Kentucky). Other states recommend SMZ width increases based on broad categories of slope (e.g., for $<7 \%, 35 \mathrm{ft} ; 7-20 \%, 50 \mathrm{ft}$; and $>20 \%$, $80 \mathrm{ft}[24.4 \mathrm{~m}]$ in Arkansas) or narrow slope categories (e.g., 40 additional feet for each increase of $10 \%$ in slope for perennial streams in Illinois). Additional increases are based on soil erodibility factors and stream width. For example there are $18 \mathrm{SMZ}$ width recommendations (ranging from $35 \mathrm{ft}$ to $300 \mathrm{ft}$ [91.4 m]) based on 3 soil erodibility classes and 6 slope classes for perennial streams of 0-20 feet in width in Florida. There are also 18 additional recommendations for perennial streams of 20-40 feet width, 18 for perennial streams $>40$ feet and similarly there are an additional 18 recommendations for intermittent streams. While herbicides are mobile in soil, little lateral movement has been observed through the soil profile following infiltration.

Downslope movement of herbicides occurs principally in the form of overland flow or macropore flow (Michael et al., 1989, Michael et al., 1990, Michael and 
Neary, 1991; Michael et al., 1999; Bastardie et al., 2002, Buttle and McDonald, 2002). Overland flow is a function of antecedent soil moisture conditions, precipitation rate, infiltration rates, and drainage capacity, but occurs to some extent any time the instantaneous precipitation rate exceeds the infiltration rate. When antecedent soil moisture is low, and infiltration rates are high, little downslope movement occurs until infiltration rates are exceeded. However, when antecedent soil moisture is high or the soil is saturated, infiltration rates may be exceeded quickly resulting in overland flow. Overland flow will always occur on poorly drained soils more quickly than well drained soils under the same conditions of slope, precipitation intensity and duration.

Macropore flow can also contribute to downslope movement of herbicides. When macropores such as those created by burrowing animals (moles, earthworms, etc.) and those left where roots have died and decayed are intact and prevalent on a site, flow through these channels may be very high and may move considerable amounts of herbicide and other water soluble compounds very deep in the soil (Bastardie et al., 2002). Movement through macropores may result in transport of herbicides to impermeable layers (bedrock, etc.) where they move along those impermeable layers to streams (Williams et al., 2002; Buttle and McDonald, 2002).

\subsection{STREAM IMPACTS}

Stream impacts can be projected from toxicological data compared with herbicide concentrations observed in operational treatment monitoring studies. Such projections are not straightforward because toxicological data are usually the result of highly controlled laboratory studies of static exposures that typically last from 48 to 96 hours instead of the short duration (a few minutes or hours) and pulsed concentration exposures that occur in aquatic ecosystems. In addition, indirect toxicity and cumulative effects are not measured in toxicological studies conducted in most screening laboratories. Field-based environmental fate studies provide a more complete picture of adverse impacts from herbicide use because they include considerations of direct and indirect toxicity, cumulative impacts, and considerations of trophic level functioning.

There have been several environmental fate studies conducted in North America, but three provide information on the environmental consequences of the three herbicides most commonly used in forest management. The studies reported were conducted with the commercially formulated product containing the active ingredients described below. They are the Carnation Creek Glyphosate Study, the Coosa County Hexazinone Study and the Florida Wetlands Imazapyr study.

\subsubsection{Carnation creek glyphosate study}

The study, conducted from 1984-1986 on a portion of the Carnation Creek Experimental Watershed Project, which covers $10 \mathrm{~km}^{2}$ in British Columbia, Canada, aerially applied $2 \mathrm{~kg}$ ai glyphosate $\mathrm{ha}^{-1}$ as the commercially available product 
Roundup (Reynolds et al., 1989). It assessed the short-term impacts of glyphosate on stream water, vegetation, soils, and stream biota. Long-term indirect impacts on water quality, erosion processes, and stream biota were also assessed. Many scientists were involved in the study (Reynolds, 1989), which began with the aerial spraying in September 1984 of 41.7 ha of the watershed. Application observed a $10 \mathrm{~m}$ buffer strip on each side of the streams except that two tributaries and their associated wetlands were intentionally sprayed as a part of the study. Maximum observed glyphosate concentration in water occurred 2 hours post-application $(0.162$ $\mathrm{mg} \mathrm{L}^{-1}$ ) and decreased to near the detection limit of $0.0001 \mathrm{mg} \mathrm{L}^{-1}$ within 96hours of treatment. Stream sediment glyphosate concentration peaked at $0.0068 \mathrm{mg}$ $\mathrm{kg}^{-1} 24$ days after treatment. Concentrations of glyphosate in leaf tissue peaked at $0.261 \mathrm{mg} \mathrm{kg}^{-1}$ in red alder and $0.448 \mathrm{mg} \mathrm{kg}^{-1}$ in salmonberry on day of treatment decreasing to less than 5\% of the peak within 15 days. Caged coho salmon fingerlings suffered $2.6 \%$ mortality in the tributary that was intentionally sprayed, but mortality was $8.8 \%$ in the unsprayed control tributary. The researchers found nothing to suggest the survival of coho salmon or cutthroat trout was affected by glyphosate (Holtby and Baillie, 1989). In laboratory tests, salmonid $\mathrm{LC}_{50}$ for formulated Roundup was determined to be 15 to $55 \mathrm{mg} \mathrm{L}^{-1}$ ( $\mathrm{LC}_{50}$ was $22 \mathrm{mg} \mathrm{L}^{-1}$ of the total Roundup formulation, $11 \mathrm{mg} \mathrm{L}^{-1}$ of the glyphosate isopropyl amine salt for Coho Salmon fingerlings; Chapman, 1989). There were no statistically significant impacts on periphyton or on aquatic invertebrates, but some qualitative changes in drift patterns may have occurred (Reynolds, 1989).

\subsubsection{Coosa county hexazinone study}

This study used by the USEPA for hexazinone reregistration was conducted by the U.S. Forest Service in Coosa County, Alabama, U.S.A. (Michael et al., 1999). The study conducted from 1990-1992 utilized a 290 ha portion of the Hatchet Creek drainage and included 3 watersheds, two treated and one untreated control. The study assessed the direct and indirect impacts of hexazinone applied as the commercially available products Velpar L (one watershed) and Velpar ULW (one watershed) on stream water, vegetation, litter, soil, and stream biota. The study began with the aerial application in April 1990 of $6.72 \mathrm{~kg} \mathrm{ha}^{-1}$ (3 times normal rate for this site) of hexazinone active ingredient to two watersheds.. The applicator observed a $10 \mathrm{~m}$ buffer strip on each side of the streams except that the ephemeral portions of each channel were left unprotected. Maximum observed hexazinone concentration in water occurred during application $\left(0.473 \mathrm{mg} \mathrm{L}^{-1}\right)$ and decreased to near detection limit of $0.001 \mathrm{mg} \mathrm{L}^{-1}$ within 24-hours. No damage was observed to vegetation in the SMZ, therefore the hexazinone contamination observed during application was the result of application to the ephemeral channel. All subsequent inputs (peak with first storm was $0.230 \mathrm{mg} \mathrm{L}^{-1}$ ) were of continuously decreasing concentrations and driven by precipitation events. Stream sediment hexazinone concentration peaked at $1.7 \mathrm{mg} \mathrm{kg}^{-1}$. Concentrations of hexazinone were highest in leaf tissue on the day of treatment with the liquid formulation of hexazinone 
(Velpar L) for Vaccinium sp (526 $\left.\mathrm{mg} \mathrm{kg}^{-1}\right)$, Cornus sp (702 $\left.\mathrm{mg} \mathrm{kg}^{-1}\right)$, fern (384 mg $\left.\mathrm{kg}^{-1}\right)$, and grass species $\left(626 \mathrm{mg} \mathrm{kg}^{-1}\right)$. Dissipation from leaf tissue was rapid and nearly complete in 180 days. Native fish were not affected by hexazinone in this study. Benthic macroinvertebrate diversity, population numbers, and trophic level function were unaffected by hexazinone treatment. The six principal metabolites of hexazinone were also monitored, but were not of significant concentrations in any samples analyzed (Michael et al., 1999).

\subsubsection{Florida wetlands imazapyr study}

Conducted jointly by the U.S. Forest Service and the University of Florida, Center for Wetlands with support from the National Pesticide Impact Assessment Program, and the National Council for Air and Stream Improvement, this study investigated the impacts of imazapyr applied as the commercially available product Arsenal Applicator's Concentrate at extremely high rates on benthic macroinvertebrates (Fowlkes et al., 2003). The study site, located $40 \mathrm{~km}$ north of Gainesville, Florida on the National Council for Air and Stream Improvement's Wetlands Study Site (owned by Plum Creek Timber Company) consisted of a 30 ha block of pine flatwoods with intermittent pond cypress domes. The microcosm experiment to determine toxicity of imazapyr to benthic macroinvertebrates, especially Chironomus $s p$ was conducted in a seasonally inundated, logged pond cypress dome. Microcosms were treated with $0,0.56,5.6$, and $56 \mathrm{~kg}$ imazapyr active ingredient $\mathrm{ha}^{-1}$, equivalent to $0,1,10$, and 100 times the normal prescription rate for this location. Imazapyr treatment had no statistically significant impact on taxa richness or total abundance for all taxa, dipterans, and chironomids, even at the highest treatment rate, which resulted in a water concentration of $18.7 \mathrm{mg} \mathrm{L}^{-1}$.

The results of these very large studies have consistently shown no adverse effects attributable to the respective herbicides used in forest management, even when experimental conditions utilized treatments at rates up to 100 times those normally used in forestry.

\section{SMZ Length vs. Width}

Michael and Neary (1993) have reported stream contamination from herbicide applications utilizing very conservative application technology. Both single-stem injection and soil spot treatments applied with $32.8 \mathrm{ft}(10 \mathrm{~m})$ SMZs resulted in stream contamination at levels up to approximately $0.04 \mathrm{mg} \mathrm{L}^{-1}$. While this is a very small amount, it may represent a level of contamination that cannot be eliminated by current methods of stream protection. It has been shown that herbicide contamination during operational and experimental applications when ephemeral and intermittent streams are not protected by SMZs resulted in stream contamination levels of 0.4 to $0.6 \mathrm{mg} \mathrm{L}^{-1}$ on the day of application, even in the absence of precipitation (Michael and Neary 1993, Michael et al., 1999). These contributions 
to perennial stream contamination are probably due to direct application to stream water in the unprotected ephemeral or intermittent channel. Therefore increasing the width of the SMZ subtending the perennial channel will do little to further decrease stream contamination. However, in light of the findings by Hansen (2001) that 55\% of the river system may be composed of ephemeral channels, it is reasonable to assume that increasing the protection of streams to include the ephemeral channels would decrease the amount of stream contamination from aerial applications. Contamination of streams at levels up to $0.04 \mathrm{mg} \mathrm{L}^{-1}$ may be unavoidable, but this is a ripe area for research. It should also be pointed out that soil type does play a role and there may be differences to be observed in other physiographic provinces, i.e., mountains and coastal plain.

\section{Conclusions}

BMPs provide some guidelines for protection of water quality and some of these guidelines are well founded in science and practicality. The most important features are the guidelines that govern handling of silvicultural chemicals and SMZ width recommendations. Increasing SMZ width beyond $10 \mathrm{~m}$ on each side of the channel may not provide much additional protection against water contamination from the use of silvicultural chemicals. It is clear that protection of the intermittent and ephemeral channels may provide much additional protection for water quality, especially in reference to erosion and sedimentation but these are outside the scope of this discussion and have been covered in other papers at this symposium.

The degree of stream contamination observed during use of silvicultural chemicals compares favorably with current toxicological data and indicates that most contamination results in drinking water quality well within EPA's HAL standards. Field studies that have been conducted with glyphosate, hexazinone, and imazapyr indicate that little or no adverse aquatic ecosystem impacts are to be expected. Hexazinone has been widely studied, but fewer environmental fate and impact studies have been conducted on glyphosate, imazapyr, sulfometuron, metsulfuron, and both the butoxyethyl ester (Garlon 4E) and triethylamine salt (Garlon 3A) of triclopyr. Studies to corroborate the few that have been conducted on glyphosate, imazapyr, sulfometuron, metsulfuron, and both the butoxyethyl ester (Garlon 4E) and triethylamine salt (Garlon 3A) of triclopyr are needed.

It should also be noted that additional regulation concerning allowable stream contamination levels may be set by local governments and other agencies that are not bound by the same regulations limiting EPA authority under FIFRA to considerations of 'unreasonable adverse effects'. In the absence of the unreasonable adverse effects clause, zero-tolerance in reference to stream contamination with silvicultural chemicals may become wide spread. Learning everything possible now concerning how we can limit silvicultural chemical incursion into streams and its biological implications may become very important to the future availability 
of silvicultural chemicals. Ephemeral and intermittent channel protection will be a very important step in this process.

\section{Knowledge Gaps}

Currently, it appears that use of silvicultural chemicals according to manufacturers' label directions, and following states' BMPs is sufficient to protect streams from significant impacts. Even when moderate impacts occur, they are localized and temporal in scale. It should be noted, however, that there is a lot we do not know. Secondly it should be noted that some areas of the U.S. are moving in the direction of zero tolerance. Zero tolerance is defined largely by the skill and capability of the chemist whose goal is to continue to improve. Thirty years ago, chemical analysis to the parts per million ( $\mathrm{ppm}$ ) was possible, but for many compounds this really stretched technology. Today it is possible to analyse at the ppb level routinely and in many cases it is relatively easy to go a thousand times lower to the parts per trillion (ppt) level. Within a few years, we may be routinely analysing at the ppt level. Analytical capability is improving at a much greater rate than our ability to preclude stream contamination. It is important, therefore, to improve our knowledge base concerning the impacts of silvicultural chemicals on water quality with all its ramifications. It is also important to improve our ability to minimize stream pollution to the greatest extent possible so that forest management for production of consumer needs can continue regardless of the social agenda imposed on that management. I offer the following as some of our data gaps and research needed:

1. Soluble contaminants (pesticides and nutrients) are carried in both sheet flow and in concentrated flow during overland flow conditions. Sheet flow is not usually so deep and energy is decreased by surface roughness factors while concentrated flow is less affected by surface roughness factors. In order to mitigate against stream contamination, it will be necessary to know how to decrease the energy of concentrated flow or how to avoid it.

2. Macropore flow contributes to the contamination of streams and it occurs very rapidly. Assessment of macropore capacity in soils near to streams and how to intervene in this flow path is not known.

3. Sorption and uptake of nutrients and pesticides in SMZs may reduce the amount moving to streams. Surface roughness, species composition and density, and soil structure are components of this process that must be understood in order to provide information on SMZ design to maximize sorption and uptake.

4. Minimum amount and structure of ephemeral channel protection required to optimize water quality protection is not known. Extension of even minimal protection to ephemeral and intermittent channels while decreasing SMZ width for higher order channels may afford greater water quality protection and reduce production losses due to the land base tied up in SMZs. This may 
be the most productive area of research for knowledge gaps in silvicultural BMPs.

5. A key factor in design of SMZs is the knowledge of threshold contamination levels below which no unacceptable adverse impacts will occur. While there has been much research on the environmental impacts of different pesticides, little is known about the potential synergism or antagonism that may occur for tank mixes as they enter streams. Synergistic activity may result in adverse impacts above the sum of potential impacts for individual chemicals. In the same way antagonism may also occur. The impacts of tank mixes on water quality is not known.

\section{References}

ABCNews: 2002, Water Therapy? Parents Charged for Allegedly Forcing Girl to Drink Fatal Amount of Water (ONLINE), available from http://abcnews.go.com/sections/GMA/GoodMorning America/GMA020918Water_therapy_death.html [Accessed 25 February 2003].

AFC: (1999), Alabama's Best Management Practices for Forestry [Online], Alabama Forestry Commission, Montgomery, Alabama, 1999, 30 pp., available from http://www.pfmt.org/ BMPs/al_bmps.htm and http://www.forestry.state.al.us/bmps_table_of_content.htm [Accessed 6 February 2003]

Allender, W. J.: 1991, 'Movement of bromacil and hexazinone in a municipal site', Bull. of Environ. Contam. and Toxicol. 46, 284-291.

ARFC: 2002, Best Management Practices for Water Quality Protection [Online], Little Rock, Arkansas, Arkansas Forestry Commission, available from http://www.forestry.state.ar.us/bmp/bmp_ review.html [Accessed 6 February 2003].

Bastardie, F., Cannavacciuolo, M., Capowiez, Y., Dreuzy, J. R. de., Bellido, A. and Cluzeau, D.: 2002, 'A new simulation for modelling the topology of earthworm burrow systems and their effects on macropore flow in experimental soils', Biology and Fertility of Soils 36, 161-169.

Buttle, J. M. and McDonald, D. J.: 2002, 'Coupled vertical and lateral preferential flow on a forested slope', Water Resources Research 38, 18/1-18/17.

Chapman, P. M.: 1989, 'Salmonid toxicity studies with Roundup', in P. E. Reynolds, (ed.), Proceedings of the Carnation Creek Herbicide Workshop, Forest Pest Management Institute, Forestry Canada, Sault Ste. Marie, Ontario, Canada, pp. 257-262.

CRCD: 1998, A Practical Guide for Protecting Water Quality While Harvesting Forest Products, Connecticut Resource Conservation and Development Forestry Committee, Hartford, Connecticut, $36 \mathrm{pp}$.

DDAFS: 2002, Delaware's Forestry Best Management Practices Manual, Delaware Department of Agriculture Forest Service, Dover, Delaware, $21 \mathrm{pp}$.

DFPR: 1987, Acceptable Management Practices for Maintaining Water Quality on Logging Jobs in Vermont [Online], Department of Forests, Parks, and Recreation, reprinted in 1997, Waterbury, Vermont, available from http://www.state.vt.us/anr/fpr/forestry/waterq.pdf [Accessed 6 February 2003].

DRED: 2001, Best Management Practices for Erosion Control on Timber Harvesting Operations in New Hampshire [Online], Department of Resources and Economic Development, Concord, New Hampshire, available from http://www.nhdfl.org/publications/bmp_manual.pdf [Accessed 6 February 2003]. 
EPA: 1993, Reregistration Eligibility Decision (RED) Glyphosate, U.S. Environmental Protection Agency, Office of Prevention, Pesticides and Toxic Substances, Washington, D.C., EPA 738-R93-014, 74 pp.

FDOF: 2000, Silviculture Best Management Practices [Online], Florida Division of Forestry, Tallahassee, Florida, available from http://www.fl-dof.com/Conservation/hydrology/index.html [Accessed 6 February 2003].

FEMVTF: 2002, FIFRA Exposure Model Validation Task Force (Online), FIFRA Exposure Model Validation Task Force, available from http://www.femvtf.com/recommen.htm [Accessed 12 February 2003].

Feng, J. C. and Navratil, S.: 1990, 'Sampling for zero-time hexazinone residues in forest soil dissipation study', Can. J. For Res. 20, 1549-1552.

Fowlkes M. D., Michael J. L., Crisman T. L. and Prenger J. P.: 2003, 'Effects of the herbicide imazapyr on benthic macroinvertebrates in a logged pond cypress dome', Environmental Toxicology and Chemistry 22, in press.

GFC: 1999, Georgia's Best Management Practices for Forestry [Online], Georgia Forestry Commission, Dry Branch, Georgia, available from http://www.gfc.state.ga.us/Publications/ RuralForestry/GeorgiaForestryBMPManual.pdf [Accessed 6 February 2003].

Hansen, W. F.: 2001, 'Identifying stream types and management implications', For. Ecol. Manage. $143,39-46$.

Hausler, R. and Peterson, G.: 2001, Water Quality Best Management Practices on Forest Land [Online], Michigan State University Extension Bulletin E2770. Lansing, Michigan, http://forestry.msu.edu/extension/extdocs/E2770.pdf [Accessed 6 February 2003].

Hildebrand, L. D., Sullivan, D. S. and Sullivan, T. P.: 1980, 'Effects of roundup herbicide on populations of Daphnia magna in a forest pond', Bulletin of Environmental Contamination and Toxicology 25, 353-357.

Holtby, L. B. and Baillie, S. J.: 1989, 'Effects of the herbicide roundup on coho salmon fingerlings in an oversprayed tributary of Carnation Creek, British Columbia', in P. E. Reynolds (ed.), Proceedings of the Carnation Creek Herbicide Workshop, Forest Pest Management Institute, Forestry Canada, Sault Ste. Marie, Ontario, Canada, pp. 224-231.

IDF: 1998, Logging and Forestry Best Management Practices: Field Guide for Water Quality in Indiana, Indiana Department of Natural Resources, Division of Forestry Available from http://www.in.gov/dnr/forestry/index.html?http://www.state.in.us/dnr/forestry/bmp/log1.htm\&2 [Accessed 6 February 2003].

IDFR: 2000, Forestry Best Management Practices for Illinois [Online], Illinois Department of Natural Resources, Division of Forest Resources, Springfield, Illinois, available from http://www.siu.edu/ ilbmp/ [Accessed 6 February 2003].

IDNR: not dated, Forestry Best Management Practices [Online], Iowa Department of Natural Resources, available from http://www.state.ia.us/government/dnr/organiza/forest/bmps.htm [Accessed 6 February 2003].

KDF: 2001, Kentucky Forest Practice Guidelines for Water Quality Management [Online], University of Kentucky Department of Forestry and Kentucky Division of Forestry, University of Kentucky Cooperative Extension Service, Lexington, KY, available from http://www.ca.uky.edu/agc/pubs/for/for67/for67.htm [Accessed 6 February 2003].

LDAF: 2001, Recommended Forestry Best Management Practices for Louisana [Online], Louisana Department of Agriculture and Forestry, available from http://www.dnr.state.la.us/crm/coastmgt/ interagencyaff/nonpoint/pdf/Forest/WholeDoc.pdf and http://www.dnr.state.la.us/crm/coastmgt/ interagencyaff/nonpoint/forest_bmp/toc.htm [Accessed 6 February 2003].

Lee, C. H., Oloffs, P. C. and Szeto, S. Y.: 1985, 'Persistence, degradation, and movement of triclopyr and its ethylene glycol butyl ether ester in a forest soil', J. Agric. Food Chem. 34, 1075-1079.

Lym, R. G. and Swenson, O. R.: 1991, 'Sulfometuron persistence and movement in soil and water in North Dakota', J. Environ. Quality. 20, 209-215. 
MBPC: (not dated), Forest Herbicides FAQs [Online], Maine Board of Pesticide Control, available from http://www.state.me.us/agriculture/pesticides/forest_herbicides_faq.htm [Accessed 6 February 2003].

MDC: 2000, Forest Management for Missouri Landowners [Online], Missouri Department of Conservation, Jefferson City, Missouri, available from http://www.conservation.state.mo.us/ documents/forest/private/forest_manag.pdf [Accessed 6 February 2003].

MDEP: 2000, Chapter 1000: Guidelines for Municipal Shoreland Zoning Ordinances [Online], Maine Department of Environmental Protection, available from http://www.state.me.us/dep/ blwq/docstand/szpage.htm\#rule [Accessed 6 February 2003].

MDEQ: not dated, Water Quality Management Practices on Forest Land, Michigan Department of Environmental Quality, Lansing, Michigan, $51 \mathrm{pp}$.

MFC: 2000, Best Management Practices for Forestry in Mississippi [Online], Mississippi Forestry Commission Publication 107, Jackson, Mississippi, available from http://www.mfc.state.ms.us/ pdf/bmp2000.pdf [Accessed 6 February 2003].

MFRC: (1999), Sustaining Minnesota Forest Resources: Voluntary Site-Level Forest Management Guidelines for Landowners, Loggers and Resource Managers [Online], Minnesota Forest Resources Council, St. Paul, Minnesota, available from http://www.frc.state.mn.us/ FMgdline/Guidebook.html [Accessed 6 February 2003].

Michael, J. L., Neary, D. G. and Wells, M. J.: 1989, 'Picloram movement in soil solution and streamflow from a coastal plain forest', J. Environ. Qual. 18, 89-95.

Michael, J. L., Neary, D. G., Gjerstad, D. and D'Anieri, P.: 1990, 'Use, fate, and risk assessment of forestry herbicides in the southern United States', in Proceedings XIX IUFRO World Congress, 5-11 August, 1990; Montreal, Quebec, Canada: Canadian International Union of Forestry Research Organizations World Congress Organizing Committee: Vol. 2, 300-311.

Michael, J. L. and Neary, D. G.: 1991, 'Fate and transport of forestry herbicides in the South: Research knowledge and needs', Proc. 6th Biennial South. Silvic. Res. Conf. 2, 641-649.

Michael J. L. and Neary, D. G.: 1993, 'Herbicide dissipation studies in southern forest ecosystems', Environmental Toxicology and Chemistry 12, 405-410.

Michael J. L., Webber E. C., Bayne D. R., Fischer J. B., Gibbs H. L. and Seesock W. C.: 1999, 'Hexazinone dissipation in forest ecosystems and impacts on aquatic communities', Canadian Journal of Forest Research 29, 1170-1181.

Michael, J. L.: 2000, 'Chapter 13: Pesticides', (Online), pp. 139-150, in Drinking Water from Forests and Grasslands - A Synthesis of the Scientific Literature, George E. Dissmeyer (ed.), 248 pp. GTR-SRS-39, available from http://www.srs.fs.fed.us/pubs/gtr/gtr_srs039/index.htm [Accessed 12 February 2003].

Michael, J. L.: 2003, 'Environmental fate and impacts of sulfometuron on watersheds in the southern United States', J. Environ. Qual. 32, 456-465.

NCDFR: 1989, Forestry Best Practices Manual [Online], North Carolina Division of Forest Resources, Raleigh, North Carolina, available from http://www.dfr.state.nc.us/water_quality/ pdf/bmpmanual.pdf [Accessed 6 February 2003].

NCDFR: 2003, Operational BMPs: Streamside Management Zones (SMZs) [Online], North Carolina Division of Forest Resources, Raleigh, North Carolina, available from http://www.dfr.state.nc.us/ stewardship/family_forest/ff_operationalbmp.htm [Accessed 6 February 2003].

NFS: 1998, Forestry Best Management Practices for Nebraska [Online], Nebraska Forest Service, University of Nebraska, Lincoln, Nebraska, available from http://www.ianr.unl.edu/ pubs/forestry/nfs/nfs-1.htm [Accessed 6 February 2003].

NJBFM: 1995, New Jersey Forestry and Wetlands Best Management Practices Manual, New Jersey Bureau of Forest Management, Trenton, NJ, 31 pp.

NYS: 2000, Best Management Practices for Water Quality: The BMP Field Guide, New York State, Department of Conservation. Albany, NY. 
ODNR: 1992, BMPs for Erosion Control on Logging Jobs in Ohio, Ohio Department of Natural Resources, Division of Forestry, Columbus, Ohio, 53 pp.

Payne, N. J., Helson, B. V., Sundaram, K. M. S. and Fleming, R. A.: 1988, 'Estimating buffer zone widths for pesticide applications', Pest. Sci. 24, 147-161.

Payne, N. J., Feng, J. C. and Reynolds, P. E.: 1990, 'Off-target deposits and buffer zones required around water for aerial glyphosate applications', Pest. Sci. 30, 183-198.

PDEP: 1999, Controlling Erosion and Sediment from Timber Harvesting Operations, Pennsylvania Department of Environmental Protection, Harrisburg, PA, 24 pp.

PIP: 1993, Metsulfuron-Methyl (Online), Pesticide Information Project, Cooperative Extension Offices of Cornell University, Ithaca, NY; Michigan State University, Lansing, MI; Oregon State University, Corvallis, OR and University of California at Davis, Davis, CA, http://pmep.cce. cornell.edu/profiles/extoxnet/metiram-propoxur/metsulfuron-methyl-ext.html [Accessed 12 February 2003].

PSU: 1999, Best Management Practices for Pennsylvania Forests, Pennsylvania State University, College of Agricultural Sciences, University Park, PA, 48 pp.

Rahman, A., James, T. K. and Sanders, P.: 1993, 'Leaching and movement of imazapyr in different soil types', in Proc. Forty-Sixth New Zealand Plant Protection Conference, Christchurch, New Zealand, 10-12 August 1993, New Zealand Plant Protection Society, Rotorua, New Zealand, pp. 115-119.

Reynolds, P. E., Scrivener, J. C., Holtby, L. B. and Kingsbury, P. D.: 1989, 'An overview of Carnation Creek herbicide study: Historical perspective, experimental protocols and spray operations', in P. E. Reynolds (ed.), Proceedings of the Carnation Creek Herbicide Workshop, Forest Pest Management Institute, Forestry Canada, Sault Ste. Marie, Ontario, Canada, pp. 15-26.

Reynolds, P. E. (ed.): 1989, Proceedings of the Carnation Creek Herbicide Workshop, Forest Pest Management Institute, Forestry Canada, Sault Ste. Marie, Ontario, 349 pp.

Roy, D. N., Konar, S. K., Charles, D. A., Feng, J. C., Prasad, R. and Campbell, R.A.: 1989, 'Determination of persistence, movement, and degradation of hexazinone in selected Canadian boreal forest soils', J. Agric. Food Chem. 37, 443-447.

SCFC: (not dated), Best Management Practices [Online], South Carolina Forestry Commission, Columbia, South Carolina, available from http://www.state.sc.us/forest/refbmp.htm [Accessed 6 February 2003].

SERA: 1998, Sulfometuron Methyl (Oust) Risk Assessment, Syracuse Environmental Research Associates, Inc. SERA TR 98-21-09-02d, prepared under USDA/FS Contract No. 53-3187-5-12, Order No. 43-3187-7-0408, Syracuse Environmental Research Associates, Inc., Fayetteville, NY, $211 \mathrm{pp}$.

SERA: 1999, Imazapyr Risk Assessment, Syracuse Environmental Research Associates, Inc. SERA TR 98-21-14-01b, prepared under USDA/FS Contract No. 53-3187-5-12, Order No. 43-3187-80222, Syracuse Environmental Research Associates, Inc., Fayetteville, NY, 202 pp.

Stephenson, G. R., Solomon, K. R., Bowhey, C. S. and Liber, K.: 1990, 'Persistence, leachability, and lateral movement of triclopyr (Garlon) in selected Canadian forestry soils', J. Agric. Food Chem. 38, 584-588.

TDADF: 1993, Guide to Forestry Best Management Practices [Online], Tennessee Department of Agriculture, Division of Forestry, Nashville, Tennessee, available from http://www.state.tn.us/ agriculture/forestry/BMPs.pdf [Accessed 6 February 2003].

TDADF: 2000, Substance of Proposed Rules. New Rule Chapter 0080-7-2 Silvicultural Best Management Practices (BMP) [Online], Tennessee Department of Agriculture, Division of Forestry, Nashville, Tennessee, available from http://www.state.tn.us/environment/wpc/forestry.htm [Accessed 6 February 2003].

Teske, M. E. and Ice, G. G.: 2002, 'A one-dimensional model for aerial spray assessment in forest streams', Journal of Forestry 100, 40-45. 
TFS: 2000, Texas Best Management Practices for Silviculture [Online], Texas Forest Service, Lufkin, Texas, available from http://txforestservice.tamu.edu/forest_management/best_ management_practices/pdf/BMP_Handbook2000b.pdf [Accessed 6 February 2003].

Tjaden, B. and Weber, L. M.: 1998, Riparian Forest Buffer Design, Establishment, and Maintenance [Online], College of Agriculture and Natural Resources, University of Maryland, publication FS725, available from http://www.agnr.umd.edu/MCE/Publications/Publication.cfm?ID=13 [Accessed 6 February 2003].

USDA: 1984, Pesticide Background Statements. Volume 1. Herbicides, U.S. Department of Agriculture, Forest Service, Agriculture Handbook Number 633, Washington, DC, pp. D19-D134.

U.S. EPA: 1993, Registration Eligibility Decision (RED). Glyphosate (Online), document EPA738-F-93-011, Washington, D.C.: U.S. Environmental Protection Agency Office of Prevention, Pesticides and Toxic Substances, Washington, DC, available from http://www.epa.gov/oppsrrd1/ REDs/old_reds/glyphosate.pdf [Accessed 12 February 2003).

U.S. EPA: 1994, Reregistration Eligibility Decision (RED). Hexazinone, document EPA-738-R94-022, U.S. Environmental Protection Agency Office of Prevention, Pesticides and Toxic Substances, Washington, DC, 233 pp.

U.S. EPA: 1998, Reregistration Eligibility Decision (RED). Triclopyr (Online), document EPA738-R-98-011, Washington, D.C.: U.S. Environmental Protection Agency Office of Prevention, Pesticides and Toxic Substances, Washington, DC, available from http://www.epa.gov/ oppsrrd1/REDs/2710red.pdf [Accessed 12 February 2003].

UTAES: (1995), Forest Practice Guidelines for Tennessee [Online], Publication 1523, University of Tennessee Agricultural Extension Service, available from http://www.utextension. utk.edu/pbfiles/pb1523.pdf [Accessed 6 February 2003].

VDF: 2002, Virginia's Forestry Best Management Practices for Water Quality [Online], Virginia Department of Forestry, Charlottesville, Virginia, available from http://www.dof.state.va.us/wq/wqbmp-guide.shtml [Accessed 6 February 2003].

Walker, A. and Welch, S. J.: 1989, 'The relative movement and persistence in soil of chlorsulfuron, metsulfuron-methyl and triasulfuron', Weed Research 29, 375-383.

Wauchope, R. D., Butler, T. M., Hornsby, A. G., Augustijn-Beckers, P. W. M. and Burt, J. P.: 1992, 'The SCS/ARS/CES pesticide properties database for environmental decision-making', Reviews of Environmental Toxicology and Chemistry 123, 1-164.

WDNR: 2002, Wisconsin Voluntary Site-Level Forest Management Guidelines [Online], Pub FR-226, Wisconsin Department Natural Resources, Madison, Wisconsin, available from http://www.dnr. state.wi.us/org/land/forestry/Private/FMG/completeFMG.pdf and http://www.dnr.state.wi.us/ org/land/forestry/Private/FMG/090402chapter13LR.pdf [Accessed 6 February 2003].

Williams, A. G., Dowd, J. F. and Meyles, E. W.: 2002, 'A new interpretation of kinematic stormflow generation', Hydrological Processes 16, 2791-2803.

WVDF: 2001, Best Management Practices for Controlling Soil Erosion and Sediment from Logging Operations in West Virginia, West Virginia Division of Forestry, Charleston, West Virginia, 29 pp. 